\title{
Centrum jazykov Slovenskej pol'nohospodárskej univerzity v Nitre
}

\author{
Andrea Holúbeková, Mária Fördösová
}

V rámci organizačných zmien, ktorými od akademického roku 2021/2022 prešli všetky fakulty Slovenskej pol'nohospodárskej univerzity v Nitre (SPU v Nitre), bolo vytvorené aj nové univerzitné pracovisko Centrum jazykov, ktoré vo svojej pedagogickej činnosti nadväzuje na predchádzajúcu činnost' Katedry jazykov Fakulty ekonomiky a manažmentu SPU v Nitre. Nad'alej sa zameriava na výučbu anglického, nemeckého, ruského, francúzskeho a španielskeho jazyka a slovenského jazyka pre cudzincov na jazykových úrovniach A1-C1 podla Spoločného európskeho referenčného rámca pre jazyky.

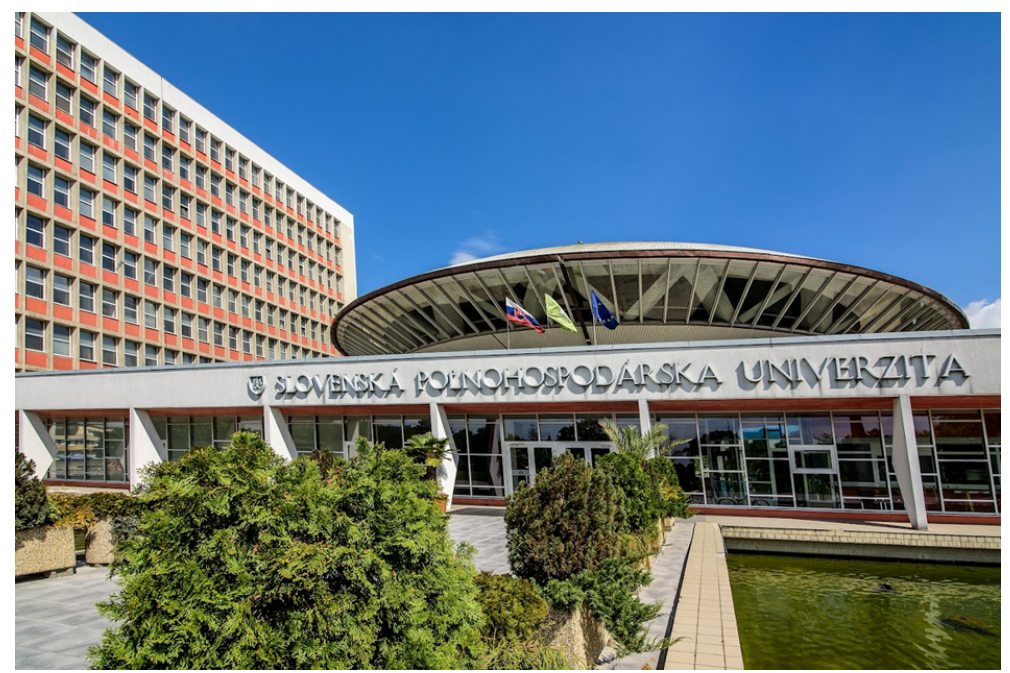

Obr. 1: Budova rektorátu SPU v Nitre (Centrum jazykov - 4., 5. poschodie) a aula (Zdroj: Archív SPU)

Činnost' Centra jazykov je do určitej miery ovplyvnená legislatívou v oblasti jazykovej politiky a celoživotného vzdelávania. V ostatnom období je úlohou vysokých škôl a univerzít vytvorit', resp. upravit' študijné programy tak, aby profil absolventov jednotlivých študijných programov zodpovedal aj konkrétnym požiadavkám zamestnávatelov na odborné vedomosti a zručnosti ako aj všeobecné spôsobilosti, ktoré sú potrebné pre výkon daného povolania. Medzi všeobecné spôsobilosti, ktoré vyžadujú zamestnávatelia, patrí aj ovládanie cudzích jazykov na požadovanej úrovni. 
Pri tvorbe informačných listov a syláb predmetov, ktoré Centrum jazykov ponúka, sa vychádza z aktuálnych požiadaviek praxe, a to konkrétne zo špecifikácie jazykových spôsobilostí, ktoré sú uvedené pri jednotlivých povolaniach v Národnej sústave povolaní. D̆alej sa berú do úvahy aj konkrétne potreby zamestnávatelov, ktoré sa týkajú dokladovania jazykových zručností budúcich zamestnancov formou vysvedčení o štátnej jazykovej skúške, jazykových certifikátov, resp. osvedčení potvrdzujúcich ovládanie cudzieho jazyka na určitej úrovni. V prostredí vysokých škôl a univerzít nefilologického zamerania uvedenej požiadavke zodpovedá jazykový certifikát UNIcert®.

Jazykový certifikát akreditovaných študijných programov v systéme UNIcert® našiel svoje uplatnenie aj v jazykovej príprave študentov a absolventov Slovenskej pol'nohospodárskej univerzity $\mathrm{v}$ Nitre. Od roku 2006 je Centrum jazykov SPU v Nitre (do 31. 8. 2021 Katedra jazykov FEM SPU v Nitre) členom Inštitútu pre akreditáciu jazykovej výučby na univerzitách strednej Európy UNIcert® LUCE s právom poskytovat' jazykovú výučbu a skúšky v akreditovaných jazykových programoch zohladňujúcich špecifiká a priority univerzity. Centrum jazykov má v súčasnosti akreditované štyri jazykové programy v systéme UNIcert ${ }^{\circledR}$ II (úroveň B2; do roku 2018 bol akreditovaný aj francúzsky jazyk) a dva jazykové programy v systéme UNIcert ${ }^{\circledR}$ III (úroveň C1; do roku 2018 bol akreditovaný aj ruský jazyk), a to konkrétne:

- Anglický jazyk pre študentov pôdohospodárskych a ekonomických vied (UNIcert® II);

- Nemecký jazyk pre študentov pôdohospodárskych a ekonomických vied (UNIcert巴 II);

- Ruský jazyk pre študentov pôdohospodárskych a ekonomických vied (UNIcert® II);

- Slovenský jazyk pre cudzincov - študentov pôdohospodárskych a ekonomických vied (UNIcert® II);

- Anglický jazyk pre ekonómov, študentov európskych štúdií a pôdohospodárskych vied so zameraním na ekonomiku (UNIcert ${ }^{\circledR}$ III);

- Nemecký jazyk pre ekonómov, študentov európskych štúdií a pôdohospodárskych vied so zameraním na ekonomiku (UNIcert@ III).

V období rokov 2006-2021 bolo na Katedre jazykov vystavených 3200 certifikátov UNIcert® II a 746 certifikátov UNIcert@ III súhrnne za všetky jazyky (vid' Tab. 1 Počet vystavených certifikátov UNIcert $\AA^{\text {II a UNIcert } ® ~ I I I), ~ p r i c ̌ o m ~ n a j v a ̈ c ̌-~}$ šiu čast' tvorili certifikáty vydané pre anglický jazyk.

Z údajov v tabul'ke vyplýva, že najvyšší počet certifikátov bol vystavený v rokoch 2007-2010, resp.v roku 2013, čo súvisí s vysokým počtom študentov na jed- 
Tab. 1: Počet vystavených certifikátov UNIcert ${ }^{\circledR}$ || a UNIcert ${ }^{\circledR}$ III

\begin{tabular}{|c|c|c|}
\hline & UNIcert $^{\circledR}$ II & UNIcert $^{\circledR}$ III \\
\hline 2006 & 35 & 19 \\
\hline 2007 & 342 & 12 \\
\hline 2008 & 685 & 34 \\
\hline 2009 & 343 & 82 \\
\hline 2010 & 273 & 56 \\
\hline 2011 & 167 & 47 \\
\hline 2012 & 150 & 41 \\
\hline 2013 & 290 & 128 \\
\hline 2014 & 177 & 72 \\
\hline 2015 & 155 & 71 \\
\hline 2016 & 196 & 72 \\
\hline 2017 & 125 & 49 \\
\hline 2018 & 150 & 43 \\
\hline 2019 & 97 & 18 \\
\hline 2020 & 12 & 2 \\
\hline 2021 & 3 & 0 \\
\hline Spolu & $\mathbf{3 2 0 0}$ & $\mathbf{7 4 6}$ \\
\hline
\end{tabular}

Zdroj: Vlastné spracovanie

notlivých študijných programoch Fakulty ekonomiky a manažmentu, ktorí majú jazykovú prípravu na skúšky v systéme UNIcert@ zahrnutú v rámci povinných predmetov, a v uvedenom období mali povinnost' zúčastnit' sa jazykovej skúšky UNIcert ${ }^{\circledR}$ II, resp. UNIcert ${ }^{\circledR}$ III v závislosti od študijného programu. Od roku 2014 počty vystavených certifikátov klesajú, čo priamo súvisí aj s klesajúcim počtom študentov hlásiacich sa na jednotlivé študijné programy ako aj so zrušením povinnosti zúčastnit’ sa jazykovej skúšky UNIcert ${ }^{\circledR}$ II, resp. UNIcert ${ }^{\circledR}$ III. V rokoch 2020-2021 bolo organizovanie skúšok obmedzené v dôsledku prísnych protiepidemických opatrení. Mnohí študenti však aj napriek tomu nadalej vítajú možnost' získat' certifikát o svojich jazykových spôsobilostiach počas štúdia na univerzite, lebo vedia, že v budúcnosti ho môžu využit' pri uchádzaní sa o zamestnanie. V súčasnom období sa pripravuje reakreditácia všetkých vyššie uvedených jazykových programov.

Centrum jazykov plánuje aj nad’alej:

- organizovat' kurzy cudzích jazykov (anglický, nemecký, ruský, francúzsky a španielsky) a slovenského jazyka pre študentov, absolventov a zamestnancov univerzity ako aj pre širokú verejnost'; 


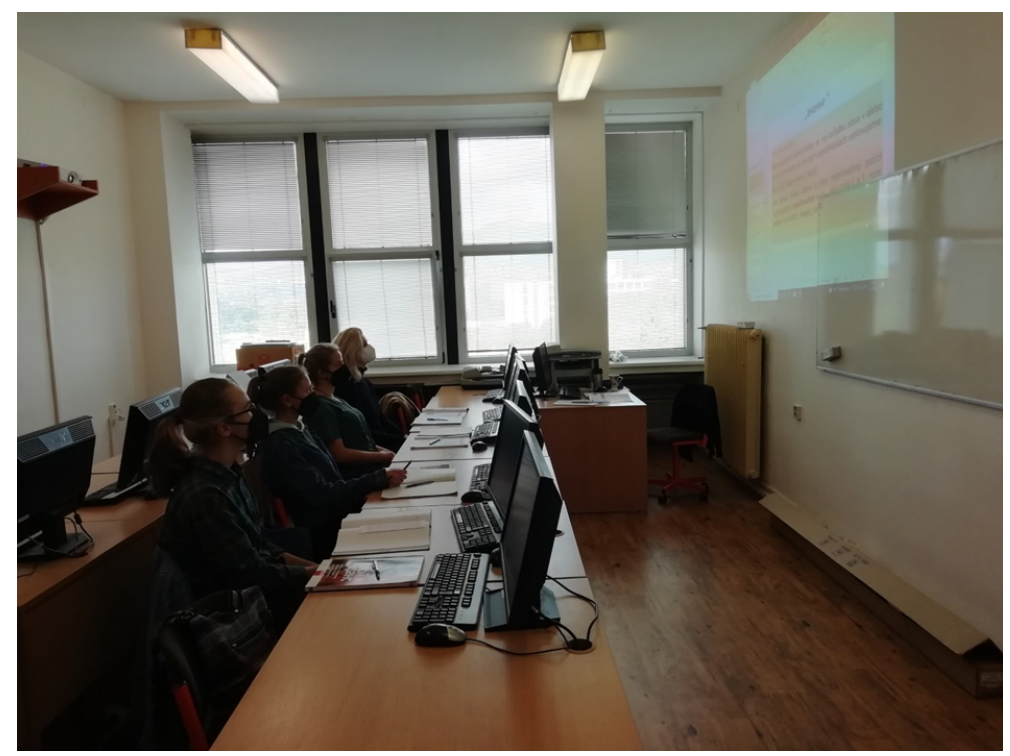

Obr. 2: Prezenčná výučba v akademickom roku 2021/2022 v počítačovej miestnosti Centra jazykov (Zdroj: Centrum jazykov)

- nadviazat’ spoluprácu s praxou a organizovat' kurzy „šité na mieru“ pre zamestnancov podnikov s cielom zlepšit' ich všeobecné spôsobilosti (ovládanie cudzieho jazyka) potrebné pre výkon daného povolania;

- aktívne sa podielat' na výučbe v rámci Univerzity tretieho veku (okrem anglického jazyka ponúknut' aj d’alšie cudzie jazyky na základe záujmu verejnosti);

- v spolupráci s Kanceláriou vnútorného systému zabezpečenia kvality organizovat’ na základe požiadavky kurzy cudzích jazykov pre vedecko-výskumných, pedagogických a nepedagogických zamestnancov univerzity;

- zúčastňovat' sa domácich a zahraničných konferencií, publikovat' príspevky v zborníkoch a časopisoch s ciel'om prezentovat' výsledky vedecko-výskumnej činnosti zamestnancov Centra jazykov a nadviazat' spoluprácu so slovenskými a zahraničnými vzdelávacími inštitúciami;

- aktívne spolupracovat' s Centrami jazykov/Katedrami jazykov na slovenských a českých nefilologických vysokých školách a univerzitách v rámci Československej asociácie učitelov cudzích jazykov na vysokých školách (CASAJC). 


\section{Autorky}

Mgr. Andrea Holúbeková, PhD., Centrum jazykov, Slovenská pol’nohospodárska univerzita v Nitre; e-mail: andrea.holubekova@uniag.sk

Andrea Holúbeková vyštudovala anglický jazyk na Filozofickej fakulte UK v Bratislave. Od roku 1997 pôsobí na Katedre jazykov FEM SPU v Nitre (od 1. 9. 2021 Centrum jazykov SPU v Nitre) ako odborná asistentka. Vyučuje anglický jazyk a špecializuje sa na odborný anglický jazyk, akademické písanie a obchodné prezentácie v anglickom jazyku. Vo svojej vedeckej a publikačnej činnosti sa venuje problematike autonómie učiaceho v kontexte výučby odborného anglického jazyka z oblasti ekonomických a pôdohospodárskych vied.

Mgr. Mária Fördösová, PhD., Centrum jazykov, Slovenská pol'nohospodárska univerzita v Nitre; e-mail: maria.fordosova@uniag.sk

Mária Fördösová vyštudovala ruský jazyk na Pedagogickej fakulte v Nitre. Od roku 2007 pôsobí na Katedre jazykov FEM SPU v Nitre (od 1. 9. 2021 Centrum jazykov SPU v Nitre) ako odborná asistentka. Vyučuje ruský jazyk (všeobecný aj odborný) na dennej aj externej forme. V publikačnej činnosti sa venuje jazykovej hre, slovenským a ruským skratkám a má skúsenosti v oblasti odbornej ruskej terminológie. 